\title{
Synthetic studies aiming structural elucidation of (-)-parviestemoamide
}

\author{
Gilmar A. Brito Jr. and Ronaldo A. Pilli* \\ Instituto de Química, Unicamp, Campinas, São Paulo, Brasil \\ *pilli@iqm.unicamp.br
}

Keywords: alkaloid, silyloxyfuran, Michael addition

\section{INTRODUCTION}

The alkaloid parviestemoamide was isolated from the roots of Stemona parviflora. The chemical structure of this compound was firstly proposed by $\mathrm{Xu}^{1}$ and coworkers (1a), but in a different work ${ }^{2}$, another structure (1) b) was suggested by the same authors, as showed in figure 1 .<smiles>NCCCCC1OC(=O)C([N+](=O)[O-])C1O</smiles>

$1 \mathrm{a}$<smiles>C[C@@H]1C(=O)O[C@H]2CCCNC(=O)CC[C@H]21</smiles>

$1 b$
Figure 1: Chemical structures proposed for the parviestemoamide alkaloid

\section{RESULTS AND DISCUSSION}

Our retrosynthetic analysis of parviestemoamide was based on the cyclization of aminoester $\mathbf{2}$, providing the parviestemoamide skeleton 1a (Scheme 1).

$$
\Longrightarrow{ }_{2}
$$

Scheme 1: Retrosynthetic analysis of parviestemoamide 1a

Aminoester 2 could be obtained by Michael addition of nitroester 4 onto benzylcarbamate $\mathbf{7}$ derived from aldehyde $\mathbf{3}$, followed by a Nef reaction.

We decided to start the synthesis of this alkaloid on a racemic approach. Based on MacMillan's strategy ${ }^{3}$ of silyloxyfuran addition onto conjugated aldehydes, we were able to prepare racemic aldehyde 3 , using an achiral organocatalyst. This aldehyde was submitted to reductive carbamoylation, resulting in protected primary amine 7 (Scheme 2).

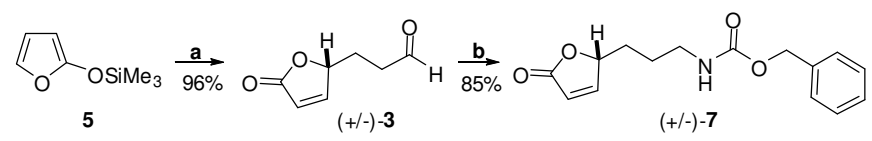

a) 2,5-dinitrobenzoic acid, $\mathrm{CH}_{2} \mathrm{Cl}_{2}-\mathrm{H}_{2} \mathrm{O}$, pirrolidine, acrolein, $-50^{\circ} \mathrm{C}, 5 \mathrm{~h}$;

b) $\mathrm{CH}_{3} \mathrm{CN}, \mathrm{H}_{2} \mathrm{NCbz}$, TFA, $\mathrm{Et}_{3} \mathrm{SiH}, 0^{\circ} \mathrm{C}-25^{\circ} \mathrm{C}, 12 \mathrm{~h}$.

Scheme 2: Synthesis of carbamate 7 by Mukaiyama-Michael addition and reductive carbamoilation
The furanone moiety of $\mathbf{7}$ was submitted to another Michael addition with nitroester 4, catalyzed by DBU. Adduct 8, had its nitro group converted to a ketone, under Nef conditions, employing potassium permanganate or trimethylphosphine (Scheme 3).

$$
\begin{aligned}
& \text { c) } \mathrm{O}_{2} \mathrm{~N}\left(\mathrm{CH}_{2}\right)_{3} \mathrm{CO}_{2} \mathrm{Me}, \mathrm{DBU}(10 \%) \text {, solvent-free, } 12 \mathrm{~h} \text {; } \\
& \text { d) } \mathrm{KMnO}_{4} \mathrm{SiO}_{2}(3 \text { eq.), benzene, reflux, 4h, 45\%; } \\
& \text { e) } \mathrm{PMe}_{3}(1 \mathrm{M}, \text { toluene, } 5 \text { eq.), } p \text { Toluyldisulfide, } \mathrm{THF}, 24 \mathrm{~h}, 52 \%(80 \%, \text { brsm); } \\
& \text { Scheme 3: Sequential Michael addition and Nef reaction } \\
& \text { toward the synthesis of advanced intermediated } \mathbf{9}
\end{aligned}
$$

After removing the nitrogen protecting group we expected to form the lactam $\mathbf{1 0}$ under acid or basic conditions. Unfortunately, only degradation products were obtained.

Future work will focus on a selective methyl ester hydrolysis and after removal of the carboxybenzyl group, aminoacid $\mathbf{1 1}$ would be obtained. Classical methods of peptide synthesis will be employed to prepare lactam $\mathbf{1 0}$ that could be converted to 1a, after further modifications (Scheme 4).

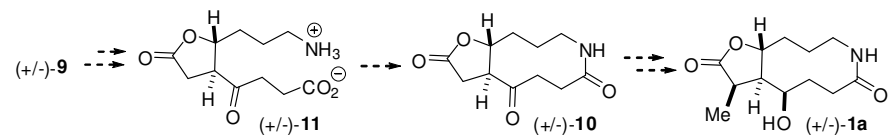

Scheme 4: Proposed final steps aiming to the total synthesis of $(+/-)-\mathbf{1 a}$

\section{CONCLUSION}

In this work, we were able to prepare an advanced intermediate toward the parviestemoamide skeleton. At present, methyl ester hydrolysis conditions are under study and next, the peptide synthesis methods will be employed, aiming the structural elucidation of this alkaloid.

\section{ACKNOWLEDGEMENTS}

The authors are grateful to Fapesp and CNPq for financial support.

\section{REFERENCES}

${ }^{1}$ Lin, W. -H.; Xu, R. -S.; Zhong, Q. -Z. Acta Chim. Sinica 1991, 49, 927

${ }^{2}$ Xu, R. -S.; Tang, Z. -J.; Feng, S. C.; Yang, Y. -P.; Lin, W. -H.; Zhong, Y. Mem. Inst. Oswaldo Cruz 1991, 86, 55.

${ }^{3}$ MacMillan, D. W. C.; Goodwin, N. C.; Brown, S. P. J. Am. Chem. Soc. 2003, 125, 1192-1194. 